\title{
Visual Media Usage Teaching in the Special Education Integration Programme (SEIP) of Hearing Impairment in Hulu Selangor
}

\author{
Abdul Rahim Razalli, Noreha Yusuf, Rahimah Kassim, Nordin Mamat \\ Universitas Pendidikan Sultan Idris, Malaysia. \\ e-mail : rahim.r@fppm.upsi.edu.my
}

\begin{abstract}
This study was conducted to identify the level of usage of visual media in teaching at the Special Education Integration Programme (SEIP) Hearing Impairment. The study also identified the attitude towards the use of visual media and the limitations faced by teachers when using visual media. The findings show the use of visual media in teaching at SEIP Hearing Impairment in Hulu Selangor is in the high level and the teacher have very positive attitude towards visual media. However, the limitations faced by teachers in the use of visual media are on the high level. This research involved 50 respondents from a special education teacher who teaches in nine (9) schools of SEIP Hearing Impairment in Hulu Selangor. Questionnaires were used as research instruments and data collection was done using 5-point Likert scale. These data were processed using Software Statistical Packages For The Social Science 20. The analysis made in descriptive statistical methods in the form of frequency, percentage and mean. Results from this study indicate the level of visual media usage among teachers in SEIP Hearing Impairment are at high level (mean $=3.52)$, while teachers' attitudes were very positive (mean $=4.43)$. There are limitations of the study showed that teachers face in SEIP of Hearing Impairment is high (mean = 3.59). Based on the findings, some suggestions are brought forward to enhance the use of visual media in teaching at SEIP Hearing Impairment.
\end{abstract}

Keywords:special education integration programme, hearing impairment, visual media

Hearing loss prevents children with hearing problems to communicate through listening and speaking. Their failure to communicate and converse also prevents them to understand lesson delivered by teachers thus impede their social and academic development in education (Razalli et al., 2016). However, according to Din (2003), the involvement of sight showed the highest percentage in helping people to gain knowledge or learn as much as $83 \%$ as compared to other senses. Ismail Zain (2003) also stated that the act of looking at the pictures and visuals can improve a person's memory up to $40 \%$ (Othman, 2014). For students with hearing problems, visual media play an important role in teaching, learning, and information delivery.

Visual media is a teaching material with image that can be viewed and it is based on vision. The use of visual is often used together with other media in teaching and learning. The use of media such as a planned teaching modules, workbooks, videos, computers and many others enable teaching to be designed according to level of students' ability especially those who are having hearing difficulty. Visual media could also help in implementing effective teaching and learning processes.

Method of Pedagogy Education learning is still in status quo, meaning majority of teachers and students prefer to use textbooks as their primary source. Majority group of teachers are still awkward to use the visual media features such as charts, graphs, video, animation, multimedia, and computer mind map or the Internet as medium of teaching and conducting examinations (Phizer 2015). According to Supyan (1994 in Ashinida, Afendi \& Mohd. Shabri 2003), his study proved the effectiveness of visual media in language learning, however this method has not gained widespread attention in Malaysia except for the use of visual media in English learning.

Although there are many positive responses on the use of computer-aided instruction, especially the visual media, nevertheless there are some teachers who are still threatened by the presence of computers in their classrooms. This matter happens due to misunderstanding, lack of understanding on the role of visual media and lack of technical skills on the use of computers (Hertz, 1987, Gunter \& Murphy, 2001 in Ashinida et al.). This phenomenon certainly surprise us because most teachers are not exposed enough on the use of computers and visual media in education. Although teachers perceived very positively on the use of teaching aids, the practice of its use in the classroom is not very encouraging due to some constraints such as lack of time, insufficient materials, impractical, teaching overload, insufficient financial resources 
and unskilled at developing own teaching material. Constraints such as lack of time, insufficient materials, impractical and excessive teaching loads (Leong, Hong and Kuan, 2001).

Based on previous studies, there are some aspects that impede special education teachers for the hearing impaired students to optimize their use of visual media, attitudes and limitations in their process of teaching and learning in the classroom. Constraints in terms of type and use of visual media is the use of text, charts, graphs, video, animation, multimedia and mind maps. Constraints in terms of attitudes such as willingness, confidence, guidance and motivation. Teachers also face time constraints, financial provisions, cooperation from parents, skills and knowledge of teachers, administrators and school facilities and equipment. Therefore, this study aims to identify the use of visual media, attitudes and limitations on the use of visual media among special education teachers in the integration program.

The use of visual or learning strategy has helped many students in the teaching and learning process to be delivered effectively. This is evidenced by Norasikin in her study (2014) which uses visual aid to improve spelling skills of students with hearing problems. Mohd \& Hassan (2003) also supported that card scanning and use of images can enhance memory of the students. Teaching strategies and student-centered learning through playing while learning method using visual materials can boost students' enthusiasm in learning.

Christopher (2012) proved in his research that visual media can be used to improve student achievement. Visual media can be further extended in teaching practices for more positive effects. Chen (1997) and Ahmad Haniz Abdul Halim (2007), argued that learning through web-shaped visual aids helps in teaching process because interactivity web pages allows for learning process to be carried out with a diverse and flexible teaching designs, apart from meeting the needs of students with different cognitive level (Nikolaraizi, Vekiri, Easterbrooks, 2013).

Zainab Asilah (2014) stated that material use which involve students will make them observe, interpret and describe their lesson content. The materials also provide them with special experience and increase the students' understanding on facts, concepts and abstract material to teaching. The materials also encourage students to concentrate on teaching and speed up the learning process. The use of images also provide clear picture on teaching. According to Rosniah (2007) in her study, visual learners are those who prefer to learn by looking at new information that they learn, whether in the form of a diagram or chart. They can also describe what is being read or seen previously. This method can improve their understanding on learning and lessons delivered to them. Attractive visual learning can speed up learning ability of the students on lessons delivered to them.

Sim et al (2004) stated that teachers are regarded as school property; implementation of any educational program depends on willingness, competence, attitude, commitment, knowledge, support and skills of teachers, especially in areas that require specialized skills such as computers and technology. The researchers have concluded that current teacher training should help teachers to be positive on the use of computers (Cates \& Mcnaull 1993, in Sim et al. 2004). With this regard, visual learning can help students to relate what they have learned with previous materials. Yusuff \& Che (2002) stated that teaching can be organized if they can combine teaching with teaching aids. Azikiwe (1998) stated that teaching materials are classified into three categories, namely, materials, audio materials and equipment.

Brown (1998) also described visual teaching materials as enhanced vision and oriented material such as pictures, objects, specimens, textbooks, blackboard, bulletin boards and other printed materials and any projection or other visuals. Teachers must be aware on the advantages and limitations of each instruction medium and choose from the entire variety of angles and device or combination of devices to make it as the best teaching tool (Fidelia, 2015).

According to Din (2003) stated that attitudes and views of teachers toward knowledge enrichment process will affect their opinion on the use of visual media in their classrooms. Another study conducted by Nor \& Sharif (2014) found a very positive attitude in visual literacy in their study of visual media consumption among technical teachers. This suggests that teachers need to be aware of the commitment given to improve their professionalism. Jahoda \& Warren (1966) reported that positive attitude towards the media influences their teaching to improve teaching provided by visual media. Richard (2006) and Mwololo et al., (2011) also commented that preschool teachers need to show positive attitude towards visual media to develop, acquire and use visual media in their teaching. A study by Hassan \& Bachik (1999) found positive attitude towards the use of teaching aids are not in line with its implementation. This is due to the fact that although the school has all the hardware and software media, the teachers are found using less of the teaching aids in their classrooms.

The finding was supported by Nik Rahimi \& Kamarul Zaman (2008) who concluded that Islamic Education teachers should be positive in accepting the surge of Multimedia Communications Technology (ICT) as the latest teaching aid today. 
Table 1. Profile of respondents in frequency and percentage

\begin{tabular}{llcc}
\hline \multirow{2}{*}{ Case } & \multicolumn{1}{c}{ Category } & \multicolumn{2}{c}{ Research Findings } \\
\cline { 3 - 4 } Gender & \multicolumn{1}{c}{ Male } & Frequency & Percentage \\
\cline { 3 - 4 } Race & Malay & 41 & 48.2 \\
& Chinese & 38 & 71.8 \\
& Indian & 6 & 12 \\
Age & Others & 6 & 12 \\
& 30 years and below & 4 & 0 \\
& 31-35 years & 13 & 8 \\
& 36-40 years & 20 & 40 \\
Education & 41 years and above & 13 & 26 \\
Level & Diploma in Education & 0 & 0 \\
& First Degree & 45 & 90 \\
& Masters & 5 & 10 \\
Teaching & Ph.D & 0 & 0 \\
Experience & Less than 1 year & 4 & 8 \\
& 6-10 Years & 9 & 18 \\
& 11 years and above & 15 & 30 \\
Type of & Primary School & 35 & 70 \\
School & Secondary School & 15 & 30 \\
& & &
\end{tabular}

While another study by Mattox (1974) found that lazy teachers give impact on the use of instructional technology (ATP) because teachers often face pressure from higher authorities and lack of support (Barshah et al. 2009).

Jamian et al. (2012) stated that apart from learning content, learning aids in the form of visual media is important to draw attention of students, especially students with learning disabilities because of their short span attention. In addition to the use of electronic materials, the use of real materials (concrete) is important so that students will be able to use their touching sensory and visual observations that will increase their understanding of what is being taught by their teachers.

Based on findings by Khairuddin (2010), there are six major challenges to increase the use of instructional technology among teachers. The first challenge is to encourage teachers to produce teaching materials based on instructional technology. The second challenge is to increase the level of knowledge among teachers in instructional technology. The third challenge is to increase positive attitudes among teachers on the use of instructional technology. The fourth challenge, equipment and facilities in schools will increase the use of instructional technology among teachers. Fifthly, an administrator role in encouraging teachers to use instructional technology. Finally the sixth challenge, preparation of teachers in facing the instructional technology wave in the future.

\section{METHOD}

Overall, this study is a descriptive survey that aims to identify the level of visual media usage, attitudes and its use limitations among special education teachers in the Hulu Selangor district, Malaysia. This research uses quantitative approach method. Research samples are used for the purpose of answering the research questions. A total of 50 deaf teachers are involved to answer the questionnaires which are adapted from "The use of Visual Materials Technical Teachers" by Nor \& Sharif (2014). Quantitative data was analyzed using the Statistical Packages for the Social Science (SPSS) Version 22 for Windows. The quantitative data was analyzed according to the frequency and percentage of data collected. To test the research questions on the extent and nature of use of visual media in teaching, the questionnaire uses Likert scale of five scores which are very often (5), often (4), moderate (3), sometimes (2) seldom (1).

For the purpose of measuring attitude and limitation of questionnaire, Likert Scale of five scores is being used namely strongly agree (5), agree (4), somewhat agree (3), disagree (2) and strongly disagree (1). Data analysis was conducted to find the percentage, mean and standard deviation in the study. In determining the level of use of visual media and limitations faced by the teachers, range scale of Mazlan Hamzah's study (2000) was used as reference which is the 4 level range scale namely low $($ mean $=1.00$ mean $=2.00)$, moderate $($ mean $=2.01$ to mean $=3.00)$ and high $($ mean $=3.01$ to mean $=4.00)$ and very high (mean $=4: 01$ to mean $=$ 5.00 ), while in terms of 4 level range scale for attitude refers to negative $($ mean $=1.00$ mean $=2.00)$, negative $($ mean $=2.01$ to mean $=3.00)$, positive $($ mean $=3.01$ to mean $=4.00$ ) and strongly positive (mean $=4: 01$ to mean $=5.00$ ).

\section{FINDINGS AND DISCUSSION}

\section{Findings}

This section discusses background of the respondents that contains 7 items related to respondents' background. Analysis of data obtained is presented in frequencies and percentages for easier observation. Table 1 shows demographics of the respondents involved in frequency and percentage.

\section{Level of Use and Type of Visual Media}

Research shows that there are 3 three types of media used at a very high level namely textbooks, images and computer. Visual media for textbooks recorded the highest mean $($ mean $=4.36(\mathrm{sd}=1.0)$ or a total of 33 users or $(86 \%)$ of teachers answered very often and often on frequency of usage and four users 
$(8 \%)$ use moderate levels of textbook as main visual medium in their teaching and only three users ie $(6 \%)$ percent are seldom users. Pictorial visual media shows the value of $($ mean $=4: 34, \mathrm{sd}=0.77)$ or a total of 41 very often users $(82 \%)$ while nine users or $(18 \%)$ are at moderate level. The use of computers as visual media shows the value of $($ mean $=4.24, \mathrm{sd}=0.84)$ or a total of 41 very often and often users $(82 \%)$ and seven average users $(14 \%)$ as compared to only two users $(4 \%)$ who are not often using the computer.

There are six different types of visual media, which showed a high level of use namely objects, videos, drawings, models, mind maps and charts. Object-shaped visual media shows the value of (mean $=3.86$, $\mathrm{sd}=$ $0.80)$ for 31 very often and often users $(62 \%)$, and 18 moderate users $(36 \%)$, while only one $(2 \%)$ do not often use objects as teaching aids. For visual media in the form of video $($ mean $=3.68, \mathrm{sd}=0.89)$; painting $($ mean $=3.50, \mathrm{sd}=0.95)$; model $($ mean $=3.46, \mathrm{sd}=0.83)$; mind maps $($ mean $=3.44$; $\mathrm{sd}=0.78)$ and charts (mean $=3.34, \mathrm{sd}=0.84)$. However there are two visual media materials are at low level of usage namely animation and graphs. Animation media shows the value of (mean $=2.86, \mathrm{sd}=1.1)$ or 19 people $(38 \%)$ who are not regular users and 16 moderate users or $(32 \%)$ and 15 regular users or $(30 \%)$. The low level also shows visual media in the form of a graph with the value of (mean $=2.30$, $\mathrm{sd}=0.70)$. In sum, Table 2 shows the overall mean of distribution for respondents on the use of visual media among PPKI teachers in their teaching process is 3.528 with a standard deviation of 0.456 . These findings demonstrate that the use of visual media among teachers for hearing impaired students in PPKI is at high level.

\section{Level of Attitude on the Use of Visual Media}

The results showed all the 10 items on attitudes of teachers showed a very positive level towards the use of visual media in teaching deaf students. The highest mean item in the distribution is "I have to use visual media in teaching and learning in the hearing problem class" with the value of $($ mean $=4.62, \mathrm{sd}=4.90)$ or a total of $31(62 \%)$ of respondents answered strongly agree and 19 $(38 \%)$ of respondents agreed with this statement.

There are four items that share the same means and the same level of approval. Two of these items are "Ineed to guide students with hearing disabilities to use visual media" and the second item "I feel confident using visual media in the class of hearing impaired students". Both of these items show the same mean value (mean $=4: 48$, $\mathrm{sd}=0.50)$ with $26(52 \%)$ respondents answered strongly agree followed by 24 respondents who answered agree (48\%). Two other items that also shows the same mean and level of approval, which is (mean $=4.46, \mathrm{sd}=0.50)$ with 27 or $(54 \%)$ respondents who answered strongly agree, followed by 23 respondents or (46\%) for item "I support the use of media visual in $R \& D$ process for hearing problem class "and item" I believe that the use of visual media can enhance students' understanding on lesson ". Value (mean $=4.42, \mathrm{sd}=0.49)$ or a total of 29 respondents $(58 \%)$ answered strongly agree followed by 21 respondents or $(42 \%)$ who agreed to the statement " $I$ have more motivation in teaching using visual media in the class of hearing impaired students"

However, there are two items that share the same mean $($ mean $=4.40, \mathrm{sd}=0.57)$ but differ in level of approval for statement "I am willing to diversify the instructional visual medium" with 30 respondents (60\%) agreed and 20 respondents ( 40\%) strongly agree. While a total of 26 respondents or (52\%) agree. There are 22 respondents answered (44\%) strongly agreed and only two respondents (4\%) answered somewhat agree on the statement "I like the course to enhance my skills in building visual media for hearing". It also shows the value $($ mean $=4.38, \mathrm{sd}=0.49$ ) or an agreed statement of 31 respondents $(62 \%)$ followed by 19 respondents or $(38 \%)$ who stongly agree for the statement "I believe the use of visual media in teaching is to attract students with hearing disabilities. Even though the item "I believe the use of visual media can improve academic achievement," noted the lowest mean with the total value of $($ mean $=4.26, \mathrm{sd}=0.44)$ or $37(74 \%)$ agree that 13 responded (26\%) strongly agree but Table 3 shows an overall mean on distribution of the respondents' attitudes among PPKI teachers is 4.43 with a standard deviation of 0.354. This finding shows that teachers of PPKI show very positive attitude towards the use of visual media in teaching and learning in the classroom of students with hearing problems.

\section{Limitation on the Use of Visual Media}

The findings show three items that represent limitations on the use of visual media at a very high level. These items are in terms of media, tools, training and skill and time. For item "I will use visual media if I have the media and the hardware are available" shows the highest mean in the distribution (mean $=4.18, \mathrm{sd}=$ $0.66)$ or a total of $30(60 \%)$ respondents, 15 or $(30 \%)$ of respondents stated strongly agree, four or $(8 \%)$ agreed and only one or (2\%) disagree. As for item "I will use visual media if given training and skills" shows high in mean $($ mean $=4: 04, \mathrm{sd}=0.75)$, ie, 28 or $(56 \%)$ of respondents agreed, 13 or $(26 \%)$ of respondents stated strongly agree seven or (14\%) less agreed and only two or $(4 \%)$ stated disagree. Time factor is also a limitation for teachers of hearing problems in using the visual media. For item "I will use visual media if I have enough time" shows high mean (mean $=4.02$, $\mathrm{sd}=$ $0.79)$ represented a total of 30 or $(60 \%)$ of respondents who agreed, 12 or $(24 \%)$ of respondents stated strongly agree and six or $(12 \%)$ of respondents stated somewhat agree. Finally for strongly disagree and disagree are represented by one respondent or $(2 \%)$ representatively. 
Table 2. Levels of Use of Visual Media

\begin{tabular}{|c|c|c|c|c|c|c|c|c|}
\hline \multirow[b]{2}{*}{ Item } & \multicolumn{5}{|c|}{ Scale } & \multirow{2}{*}{ Mean } & \multirow{2}{*}{$\begin{array}{c}\text { Std } \\
\text { Dev }\end{array}$} & \multirow[b]{2}{*}{ Level } \\
\hline & $\begin{array}{c}1 \\
\mathrm{~F}(\%)\end{array}$ & $\begin{array}{c}2 \\
\mathrm{~F}(\%)\end{array}$ & $\begin{array}{c}3 \\
\mathrm{~F}(\%)\end{array}$ & $\begin{array}{c}4 \\
\mathrm{~F}(\%)\end{array}$ & $\begin{array}{c}5 \\
\mathrm{~F}(\%)\end{array}$ & & & \\
\hline Textbooks & $2(4)$ & $1(2)$ & $4(8)$ & $13(26)$ & $30(60)$ & 4.36 & 1.0 & Very high \\
\hline Picture & - & - & $9(18)$ & $15(30)$ & $26(52)$ & 4.34 & 0.77 & Very high \\
\hline Chart & - & $7(14)$ & $24(48)$ & $15(28)$ & $5(10)$ & 3.34 & 0.84 & High \\
\hline Drawing & - & $6(12)$ & $23(46)$ & $11(22)$ & $10(20)$ & 3.50 & 0.95 & High \\
\hline Poster & $1(2)$ & $12(24)$ & $25(50)$ & $10(20)$ & $2(4)$ & 3.00 & 0.83 & Low \\
\hline Graph & $6(12)$ & $24(48)$ & $19(38)$ & $1(2)$ & - & 2.30 & 0.70 & Low \\
\hline Mind Map & $1(2)$ & $2(4)$ & $25(50)$ & $18(36)$ & $4(8)$ & 3.44 & 0.78 & High \\
\hline Model & $1(2)$ & $3(6)$ & $23(46)$ & $18(36)$ & $5(10)$ & 3.46 & 0.83 & High \\
\hline Object & - & $1(2)$ & $18(26)$ & $20(40)$ & $11(22)$ & 3.82 & 0.80 & High \\
\hline Video & $1(2)$ & $4(8)$ & $12(24)$ & $26(52)$ & $7(14)$ & 3.68 & 0.89 & High \\
\hline Animation & $6(12)$ & $13(26)$ & $16(32)$ & $12(24)$ & $3(6)$ & 2.86 & 1.1 & Low \\
\hline $\begin{array}{l}\text { Computer } \\
\text { /Multimedia }\end{array}$ & - & $2(4)$ & $7(14)$ & $18(36)$ & $23(46)$ & 4.24 & 0.84 & Very high \\
\hline Overall Mean & & & & & & 3.52 & 0.45 & High \\
\hline
\end{tabular}

Note, 1-Rare; 2-Sometimes; 3-Moderate; 4-Often; 5-Very often

Table 3. Attitudes toward Using Visual Media

\begin{tabular}{|c|c|c|c|c|c|c|c|c|}
\hline \multirow[b]{2}{*}{ Item } & \multicolumn{5}{|c|}{ Approval Level } & \multirow[b]{2}{*}{ Mean } & \multirow[b]{2}{*}{$\begin{array}{l}\text { Standard } \\
\text { Deviation }\end{array}$} & \multirow[b]{2}{*}{ Level } \\
\hline & $\begin{array}{l}1 \\
\mathrm{~F}(\%)\end{array}$ & $\begin{array}{l}2 \\
\mathrm{~F}(\%)\end{array}$ & $\begin{array}{l}3 \\
\mathrm{~F}(\%)\end{array}$ & $\begin{array}{l}4 \\
F(\%)\end{array}$ & $\begin{array}{l}5 \\
\mathrm{~F}(\%)\end{array}$ & & & \\
\hline $\begin{array}{l}\text { I will use visual media if the media and } \\
\text { hardware are well provided }\end{array}$ & - & $1(2)$ & $4(8)$ & $30(60)$ & $15(30)$ & 4.18 & 0.66 & Very high \\
\hline $\begin{array}{l}\text { I will use visual media if there is sufficient } \\
\text { time }\end{array}$ & $1(2)$ & $1(2)$ & $6(12)$ & $30(60)$ & $12(24)$ & 4.02 & 0.79 & Very high \\
\hline $\begin{array}{l}\text { I will use visual media if given training and } \\
\text { skills }\end{array}$ & - & $2(4)$ & $7(14)$ & $28(56)$ & $13(26)$ & 4.04 & 0.75 & Very high \\
\hline $\begin{array}{l}\text { I am concerned that the use of visual media } \\
\text { do not help students with hearing problems } \\
\text { focus in the classroom }\end{array}$ & - & $5(10)$ & $24(48)$ & $17(34)$ & $4(8)$ & 3.40 & 0.78 & High \\
\hline $\begin{array}{l}\text { I will use visual media in there is not too } \\
\text { many workload }\end{array}$ & $2(4)$ & $8(16)$ & $15(30)$ & $20(40)$ & $5(10)$ & 3.36 & 1.0 & High \\
\hline $\begin{array}{l}\text { I will use visual media if there is support } \\
\text { from the administrators }\end{array}$ & $3(6)$ & $1(2)$ & $7(14)$ & $30(60)$ & $9(18)$ & 3.82 & 0.96 & High \\
\hline $\begin{array}{l}\text { I will use visual media if parents encourage } \\
\text { and support me }\end{array}$ & $4(8)$ & $1(2)$ & $13(26)$ & $29(58)$ & $3(6)$ & 3.52 & 0.95 & High \\
\hline $\begin{array}{l}\text { I will use visual media if there is a } \\
\text { partnership of peers }\end{array}$ & $2(4)$ & $1(2)$ & $10(20)$ & $34(68)$ & $3(6)$ & 3.70 & 0.78 & High \\
\hline The use of visual media is costly & $5(10)$ & $6(12)$ & $16(32)$ & $23(46)$ & - & 3.14 & 0.99 & High \\
\hline $\begin{array}{l}\text { I will use visual media if I am rewarded } \\
\text { with appreciation }\end{array}$ & $7(14)$ & $8(16)$ & $21(42)$ & $14(28)$ & - & 2.84 & 0.99 & Low \\
\hline Overall Mean & & & & & & 3.59 & 0.43 & High \\
\hline
\end{tabular}

There are six items which are at high level. Items on support from the administrators shows the value of (mean $=3.82, \mathrm{sd}=0.96)$ with 30 or $(60 \%)$ of respondents agreed, nine or $(18 \%)$ of respondents stated strongly agree, seven or (14\%) of respondents simply agree, strongly disagreed accounted for three or $(6 \%)$ respondents and disagreed represents one respondent (2\%). Item "I will use visual media if there is partnership among colleagues" shows the value of (mean $=3.70$, sd $=0.78)$ meaning 34 or $(68 \%)$ of respondents agreed, three or $(6 \%)$ of respondents stated strongly agree, 10 or $(20 \%)$ of the respondents agree, disagree accounted for one respondent or $(2 \%)$. Strongly disagree accounted for two respondents or (2\%). Limitations in terms of support and encouragement of parents showed high level (mean $=3.52, \mathrm{sd}=0.95)$ with 28 or $(58 \%)$ respondents agree, 3 or $(6 \%)$ of respondents strongly agreed, 13 or $(26 \%)$ simply agreed followed by one respondent or ( $2 \%$ ) disagreed and two or $(4 \%)$ of respondents strongly disagree. 
Tabel 4. Approval Level

\begin{tabular}{|c|c|c|c|c|c|c|c|c|}
\hline \multirow[b]{2}{*}{ Item } & \multicolumn{5}{|c|}{ Approval Level } & \multirow[b]{2}{*}{ Mean } & \multirow{2}{*}{$\begin{array}{l}\text { Standard } \\
\text { Deviation }\end{array}$} & \multirow[b]{2}{*}{ Level } \\
\hline & $\begin{array}{c}1 \\
\mathrm{~F}(\%)\end{array}$ & $\begin{array}{c}2 \\
\mathrm{~F}(\%)\end{array}$ & $\begin{array}{c}3 \\
\mathrm{~F}(\%)\end{array}$ & $\begin{array}{c}4 \\
\mathrm{~F}(\%) \\
\end{array}$ & $\begin{array}{c}5 \\
\mathrm{~F}(\%)\end{array}$ & & & \\
\hline $\begin{array}{l}\text { I have to use visual media in teaching and } \\
\text { learning for classes with hearing problems }\end{array}$ & - & - & - & $\begin{array}{c}19 \\
(38)\end{array}$ & $\begin{array}{c}31 \\
(62)\end{array}$ & 4.62 & 0.49 & Very positive \\
\hline $\begin{array}{l}\text { I need to guide students with hearing } \\
\text { disabilities to use visual media }\end{array}$ & - & - & - & $\begin{array}{c}26 \\
(52)\end{array}$ & $\begin{array}{c}24 \\
(48)\end{array}$ & 4.48 & 0.50 & Very positive \\
\hline $\begin{array}{l}\text { I feel confident using visual media in class } \\
\text { with hearing problem }\end{array}$ & - & - & - & $\begin{array}{c}26 \\
(52)\end{array}$ & $\begin{array}{c}24 \\
(48)\end{array}$ & 4.48 & 0.50 & Very positive \\
\hline $\begin{array}{l}\text { I support the use of visual media in the } \\
\text { teaching and learning processes for classes } \\
\text { with hearing problems }\end{array}$ & - & - & - & $\begin{array}{c}27 \\
(54)\end{array}$ & $\begin{array}{c}23 \\
(46)\end{array}$ & 4.46 & 0.50 & Very positive \\
\hline $\begin{array}{l}\text { I became more motivated teaching using visual } \\
\text { media in the classroom with hearing problem }\end{array}$ & - & - & - & $\begin{array}{c}29 \\
(58)\end{array}$ & $\begin{array}{c}21 \\
(42)\end{array}$ & 4.42 & 0.49 & Very positive \\
\hline $\begin{array}{l}\text { I am willing to diversify my visual media } \\
\text { teachings }\end{array}$ & - & - & - & $\begin{array}{c}30 \\
(60)\end{array}$ & $\begin{array}{c}20 \\
(40)\end{array}$ & 4.40 & 0.49 & Very positive \\
\hline $\begin{array}{l}\text { I believe the use of visual media in teaching } \\
\text { could attract students with hearing disabilities }\end{array}$ & - & - & - & $\begin{array}{c}31 \\
(62)\end{array}$ & $\begin{array}{c}19 \\
(38)\end{array}$ & 4.38 & 0.49 & Very positive \\
\hline $\begin{array}{l}\text { I believe the use of visual media can enhance } \\
\text { students' understanding of lesson }\end{array}$ & - & - & - & $\begin{array}{c}27 \\
(54)\end{array}$ & $\begin{array}{c}23 \\
(46)\end{array}$ & 4.46 & 0.50 & Very positive \\
\hline $\begin{array}{l}\text { I believe the use of visual media can improve } \\
\text { academic achievement of students with hearing } \\
\text { problems }\end{array}$ & - & - & - & $\begin{array}{c}37 \\
(74)\end{array}$ & $\begin{array}{c}13 \\
(26)\end{array}$ & 4.26 & 0.44 & Very positive \\
\hline $\begin{array}{l}\text { I like to attend courses to improve my skills in } \\
\text { developing visual media for hearing disabled } \\
\text { students }\end{array}$ & - & - & $\begin{array}{c}2 \\
(4)\end{array}$ & $\begin{array}{c}26 \\
(52)\end{array}$ & $\begin{array}{c}22 \\
(44)\end{array}$ & 4.40 & 0.57 & Very positive \\
\hline Overall Mean & & & & & & 4.43 & 0.35 & Very positive \\
\hline
\end{tabular}

There are 24 or $(48 \%)$ of respondents expressed their approval at medium level for item "visual media do not help students focus in the classroom" with five respondents or $(10 \%)$ disagree, but 17 respondents or $(34 \%)$ agreed and four or $(8 \%)$ of the respondents answered strongly agree. The mean value shows the value of (mean $=4.40$, sd. 0.78$)$. Next item touches on limitations of the workload. The mean shows a value of $($ mean $=3.36, \mathrm{sd}=1.0)$ at high levels of 20 respondents or $(40 \%)$ agreed, five respondents or $(10 \%)$ strongly agreed as compared to 15 responded simply agree, eight respondents or (16\%) disagree, and two respondents or (4\%) strongly disagree.

Items related to visual media requires high costs show the value of (mean $=3.14$ sp. 0.99) which is at high level with five respondents or (10\%) strongly disagree, six or $(12 \%)$ responded disagree and 16 or $(32 \%)$ responded simple agree. A total of 23 or $(46 \%)$ of 50 respondents agreed that visual media is costly. However, the teachers do not consider appreciation as a major limitation in the use of visual media. This is shown from low mean score $($ mean $=2.84$, sd $=0.99$ ) with the respondents who do not agree accounted for 21 or $(42 \%)$ respondents, followed by disagree answered by eight respondents or $(16 \%)$ and seven or $(14 \%)$ who responded strongly disagree stated that they will use the visual media if they are given the appreciation. The results showed an overall mean value of 3.59 with a standard deviation of 0.43 . This shows the limitations faced by PPKI teachers are at high level. The distribution of the overall mean value for all items are as shown in Table 4.

\section{Discussion}

The use of visual media is important in the teaching and learning of students with hearing disabilities. This will help them to better understand particular subject better. The results showed an overall mean of distribution of the respondents on the use of visual media among PPKI special education teachers in the teaching process is 3.528 with a standard deviation of 0.456. The findings demonstrate that the use of visual media among the PPKI special education teachers are at high level.

The findings also showed that textbook is one of visual media that is very high in usage followed by computers and image. Textbooks and activity books for hearing disabled students were revised and they involved four subjects, namely Bahasa Melayu, English, Sign Language Communication and Islamic Education. Adaptation of textbooks for hearing disabled students which are complete with pictures and sign language can help teachers and students to enhance their understanding of sign language and the language itself. 
This finding is similar to a study conducted by Yasin (2010) shows the level of utilization is at moderate level, but textbooks showed high level with a mean value of 4.40. This is followed by the use of worksheet with a mean value of 4.30 and the use of workbook with a mean value of $4: 38$. While visual media that is seldom used is chart with a mean value of 3.90. The findings here clearly shows that most teachers still makes printed materials such as textbooks and worksheet as visual media of choice in teaching and learning in the classroom and it is still relevant today.

Results from a study conducted by Zainuddin et al. (2007), also found high level of teaching aid usage either electronic or non-electronic among the trainee teachers during teaching practice. The results showed that most trainee teachers use teaching aids at all times during the process of teaching and learning. Most trainee teachers as observed diversify their teaching aids.

Another study was conducted by Noor Azlan \& Nurdalina (2010) which studied the use of teaching aids among UTM trainee teachers for Mathematics. The results showed high level of teaching aid usage among UTM trainee teachers. The teachers use a variety of teaching aids during their teaching sessions. Teaching aids are divided into two, namely electronic media and non-electronic media. Among the teaching aids used by teachers are computers, OHP transparencies, mahjung paper, model - 3D model, manila cards, handouts and recyclable materials. Teachers are more likely to create and develop their own teaching aids rather than using teaching materials provided by the school.

However, study findings by Nor \& Sharif (2014) showed that teachers are more often using stationary visuals either in the form of two-dimensional posters, photographs, charts, maps and graphs or threedimensional shape such as a real model compared with the use of visual and computer. Based on the mean score, it was found that both usage is at moderate level. The findings are almost similar with findings by Jasmi Kamarul Azmi et al. (2011) who study the use of teaching aids (BBM) by Outstanding Islamic Education Teachers (GCPI). There are six types of teaching aid that form patterns of use among main GCPI which are textbooks, computers and LCD. Teaching aids that formed as secondary pattern refers to handouts and modules, mahjong paper, reference books, and pictures.

The findings discussed above however contradict with a study by Chukwu (2007) who argued that most of the teaching aid materials are not available in schools. Most of the textbooks available are already obsolete. (Offorma, 2009) and Ugwu in (Fidelia, 2015) stated that in Nigeria, teachers hardly teach because of various factors such as lack of teaching materials, poor teaching and lack of training. They also affirmed that well trained teachers will be able to design and produce materials that will meet the criteria relevant to students and learning objectives.

The use of teaching aids in visual media form, especially computer and animation by special education teachers are similar to a study by Mohd Hanafi (2013), which affirmed the use of teaching aids in special education classes is still not enough, especially with regard to latest ICT materials. The use of teaching aids is a way to improve performance and achievement for special education students because without these materials, teaching and learning process will be less effective and academic quality will decrease.

According to Satiah (2009), teachers use teaching aids and teaching materials to produce effective teaching for deaf students. The use of teaching aid can help in teaching deaf students to learn the language. Teachers are also more likely to use teaching aids produced by teachers because it meets the suitability and needs of students. This statement is very similar to the findings that indicate high level of visual media usage among special education teachers. Meaning that teachers use visual media that are self-produced or readily designed visual media.

Positive attitude of teachers determine the achievement of objectives and mastery of learning for students with hearing disabilities. The overall mean for distribution of the respondents' on attitudes of special education teachers in this study is 4.43 with a standard deviation of 0.354 . This finding suggests that special education teachers are very positive towards the use of visual media in teaching and learning in the class of hearing problems. Findings by Nor \& Sharif (2014) claimed that the obtained data showed teachers' positive attitudes toward the use of visual media in teaching. This can be seen from the high score on items that involve commitment of the teachers such as giving information, guidance and support to improve their students' understanding. This clearly shows that teachers are aware of the supposed commitment to improve their level of professionalism.

Studies by Melor et al \& Dexter Sigan (2013) concerned on perception of teachers on the use of visual aids (video, animation, photographs, films and projector) as motivational tools to increase students' interest in reading literary texts. Analysis of the data showed that majority of the teachers have positive perception of the use of visual aids. Findings by Mwololo et al., (2011) also found that schools have positive attitude towards visual media and help media users in teaching. The results showed an overall mean value of 3.59 mean showed high level of limitations faced by the special education teachers. The findings of this study are similar to study findings by Nor \& Sharif (2014) that showed two major limitations 
faced by technical teachers nmely lack of material and technical equipment and time constraints. Mean scores for both categories are high which is more than 3.9. In addition, teachers do not consider appreciation and intervention of administrator as major limitations in their use of visual media. This is shown by average value of mean score 3.00 for the appreciation item and 2.4 for objection item from the administration. In addition to receiving less intervention from administrators, teachers also received less objections from parents. This is evidenced from the low mean score (1.74) for the item nine which is receiving objections from parents. This study also shows that there are three main limitations faced by the special education teachers. The items refer to materials, tools, training, skills and time.

\section{CONCLUSION AND SUGGESTION}

The use of visual media as observed could increase the interest of students and teachers in teaching and learning. In conclusion, the use of visual media at high level apart from highly positive attitude of teachers allow the use of visual media for the benefits of students with hearing problems. To achieve this end, several obstacles must be overcome to make better teaching and learning for students with hearing problems. Media visual do assist and provide the means for achieving goal by emphasizing a particular thing or explain a particular concept or a new phenomenon.

Well-established and relevant use of visual media to students with hearing problems can improve their understanding of the media presented, facilitate learning, strengthen knowledge, explain ideas and create excitement. Visual media is one of the most effective methods to deliver any types of knowledge. Visual media will be an important tool in the special education system. Discussions and studies concerning with hearing disabled issues should be widely extended. Discussion of this paper only provides some indications of the many ways in which homes, schools and public hearings can provide an environment that is accessible and meaningful to each student with hearing disability. Continuous development will depend on how it fits with the wider educational system. Findings and discussion lead us to the conclusion that people with hearing problems can be seen as a specific group in a broader context.

Hence special education teachers should always be alert and proactive to the current media development and the latest teaching methods and their impact on students' learning process. They also need to constantly strive to develop lessons that could provide positive and significant impact on students. Their efforts not only improve the quality of teaching and learning in schools, but also generate students who can contribute for the progress of their nation.

The study found high level of visual media usage among PPKI teachers in Hulu Selangor. Therefore, special education teachers need to diversify their use of visual media, making them more modern and advanced in line with current technologies. The conventional approach needs to be enhanced in a way that is more effective and up to date thus learning environment for students with hearing disabilities will be better and more meaningful.

There are various factors that affect special education teachers in using visual media for teaching purpose. Factors such as skills, experience and positive attitude towards the concept of visual media should be made clear. Therefore the teachers should be aware of education scenarios around them. The advantages of electronic media in education needs to be benefited by the media because it helps in capabilities of input, display, storage, retrieval, copying, procurement, transportation, manipulation, calculation, simulation and animation. Teachers must also have good attitude, personality and integrity. Thus the role of teachers is not limited to knowledge that they have but also in response to equipment that they use in class, workshop or laboratory.

Within school environment, teachers use sign language as their main medium for conversation, teaching and communication. Thus mastery of efficiency in adapting the visual media to dominate BIM Sign Language, KTBM and ASL in visual form must be optimized. The school environment must be conducive and meet the needs of teachers and students with hearing disabilities. It must be equipped with a variety of facilities such as printed material in the text, computer, visual and notes to assist the learning process and the effort to meet the academic requirements, as well as the needs of students (Spencer \& Marschark 2010).

\section{REFERENCES}

Cerra, K. K., Watts-Taffe, S., \& Rose, S. (1997). Fostering reader response and developing comprehension strategies in deaf and hard of hearing children. American annals of the deaf, 142(5), 379-386.

Christoper, L. W. F. (2012) Kesan Penggunaan Bahan Bantu Mengajar Visual Dalam Pengajaran Subjek Sains Tahun 3. Koleksi Artikel Penyelidikan Tindakan PISMP Prasekolah Amb. Seminar Penyelidikan Tindakan IPG KBL

Din, A. G. M. (2003). Prinsip dan amalan pengajaran. Kuala Lumpur: Utusan Publications \& Distributors Sdn Bhd. 
Fidelia, O. A. (2015). Material Teaching Aids: Enhancement Tool for Teaching Essay Writing in Secondary Schools. World Journal of Education, 5(5), 110.

Hallahan, D. P \& Kaufman. J. M, (1991). Expetional Children : Introduction To Education. $5^{\text {th }}$ Edition. New Jersey :Prince Hall. Inc

Hassan, J., \& Bachik, A. (1999). Permasalahan Penggunaan Abm Dalam Pengajaran Khb Di Sek. Men. Daerah Kota Tinggi, Johor (Doctoral dissertation, Universiti Teknologi Malaysia).

Hoffman, M., \& Wang, Y. (2010). The use of graphic representations of sign language in leveled texts to support deaf readers. American annals of the deaf, 155(2), 131-136.

Jamian, A. R., Othman, S., \& Hashim, H. (2016). Persepsi Guru Terhadap Penggunaan Kartun dalam Transformasi Pengajaran Penulisan Karangan Bahasa Melayu. Jurnal Pendidikan Bahasa Melayu, 2(1), 128-140.

Mohd, A., \& Hassan, A. (2003). Belajar berfikir. PTS Professional.

Mwololo, J. N., Barbara, G. K., Nyakwara, B., \& Mutweleli, S. M. (2011). Pre-school teachers' knowledge and attitude towards use of visual media in instructional delivery in Kibwezi District, Kenya.

Nikolaraizi, M., Vekiri, I., \& Easterbrooks, S. R. (2013). Investigating deaf students' use of visual multimedia resources in reading comprehension. American annals of the deaf, 157(5), 458-473.

Nor, A. M., \& Sharif, S. (2014). Penggunaan Bahan Visual Di Kalangan Guru Teknikal. Jurnal Pemikir Pendidikan, 5.

Othman, A. H. H. (2014) Penggunaan Gambar Rajah Dalam Meningkatkan Kemampuan Murid Mengingat Maksud Isra' Dan Mikraj Murid Tahun 5. Institut Pendidikan Guru, Kampus Dato ${ }^{\text {ee Razali }}$ Ismail.

Razalli, A. R., Mamat, N., \& Low, L. K. (2016). Bahasa Melayu Hand Coded and Malaysian Sign Language Acquisition of Hearing Impaired Students ar Early Intervention. World Academy of Science, Engineering and Technology 2016. Sydney

Richard, M. G (2006). Special Education In Contemporary Society : An Introduction To Exceptionality, $2^{\text {nd }}$ Edition Usa : Thomson Wadsworth

Wright, A., \& Haleem, S. (1991) Visuals For The Language Classroom Longman Keys To Language Teaching. London: Longman.
Yasin, H. B. M. (2010). Penggunaan alat bantu mengajar (ABM) di kalangan guru-guru teknikal di Sekolah Menengah Teknik Daerah Johor Bahru, Johor. Universiti Teknologi Malaysia

Yusuff, A., \& Che, R. M. (2002) Proses Pendengaran Dan Kecatatan Bahasa : Dewan Bahasa Dan Pustaka. receive from Http://Www.Angelfire. Com/Journal2/ Abdullahyusoff/ Proses Pendengaran.Html 